\title{
Procedure for consideration of individual labor disputes in the republic of Uzbekistan
}

\section{Lola RAHIMQULOVA ${ }^{1}$}

Labor Law Department

\begin{tabular}{l} 
ARTICLE INFO \\
\hline Article history: \\
Received September 2020 \\
Received in revised form \\
15 November 2020 \\
Accepted 20 November 2020 \\
Available online \\
15 December 2020 \\
\hline
\end{tabular}

\section{Keywords:}

Labor dispute

Commission

Labor conflict

Labor legal relationship

\begin{abstract}
This article analyzes the concept of labor disputes on the basis of studying the experience of other countries, and is also posted on the portal for discussion of draft regulatory legal acts. In order to improve the relevant norm of the draft Labor code of the Republic of Uzbekistan, a proposal has been developed. The author elaborated on the main reasons that caused labor disputes. The advantages of the work of the labor dispute Commission in the company's activities are analyzed.

2181-1415/@ 2020 in Science LLC.

This is an open access article under the Attribution 4.0 International (CC BY 4.0) license (https://creativecommons.org/licenses/by/4.0/deed.ru)
\end{abstract}

\section{Ўзбекистон республикасида якка мехнат низоларини кўриб чиқиш тартиби}

\begin{tabular}{l}
\hline Калит сузлар: \\
Мехнат низоси \\
Комиссия \\
Мехнат низоси \\
Мехнат хукуқий \\
муносабатлари
\end{tabular}

\begin{abstract}
АННОТАЦИЯ
Мазкур мақолада мехнат низолари тушунчаси бошқа давлатлар тажрибасини ўрганган холда тахлил қилинган хамда норматив хуқуқий-хужжатлар лойихалари мухокамаси порталига жойлаштирилган Ўз.Р.Мехнат кодекси лойихасининг тегишли нормасига такомиллаштириш мақсадида таклиф ишлаб чиқилган. Муаллиф томонидан мехнат низоларини вужудга келтирувчи асосий сабабларга батафсил кўриб чиқилган. Мехнат низолари комиссиясининг корхона фаолиятидаги афзалликлари тахлил қилинган.
\end{abstract}

\footnotetext{
1 Teacher of the Labor Law Department of Tashkent State University of Law

E-mail:1.rahimqulova@tsul.uz
} 


\section{Порядок рассмотрения индивидуальных трудовых споров в республике Узбекистан}

\author{
Ключевые слова: \\ Трудовой спор \\ Комиссия \\ Трудовой конфликт \\ Трудовые \\ правоотношения
}

АННОТАЦИЯ

\begin{tabular}{l}
\hline В данной статье понятие трудовых споров \\
анализируется на основе изучения опыта других стран, а \\
также размещен на портале обсуждений проектов \\
нормативных правовых актов. В целях совершенствования \\
соответствуюей нормы проекта Трудового кодекса \\
Республики Узбекистан разработано предложение. Автор \\
подробно остановился на основных причинах, вызвавших \\
трудовые споры. Проанализированы преимущества работы \\
комиссии по трудовым спорам в деятельности предприятия
\end{tabular}

Бугунги кунда мехнат низоларини кўриб чиқиш ва хал этиш масаласи нафақат мехнат хуқуқида, балки хукумат даражасида эътибор қаратилган долзарб мавзулардан бири хисобланади. Хусусан, 2020 йилдаги «Илм, маърифат ва рақамли иқтисодиётни ривожлантириш йили» Давлат дастурида хам мехнат низоларини муқобил йўллар билан хал этиш чора-тадбирларини кучайтириш лозимлиги таъкидланган.

Ушбу мавзунинг долзарблигини куйидагича асослаш мумкин: Бозор иқтисодига асосланган жамиятда фикрларнинг хилма-хил бўлиши, манфаатлар тўқнашуви, мехнат қонунчилигини қўллаш юзасидан ўзаро қарамақаршиликларнинг вужудга келиши табиий хол хисобланади. Мехнат низолари фалсафий нуқтаи назардан олганда жамият хаётидаги объектив ходиса ва қарамақаршиликлар бирлиги хамда кураш жараёни динамикасини ифодалайди. Ишлаб чиқариш ва унга оид ижтимоий муносабатлар бор экан, унинг бағрида зиддиятлар хам мавжуд бўлиши муқаррар. Зиддиятларнинг мавжудлиги тараққиётнинг объектив шартидир.[1]

Вужудга келган мехнат низолари мехнат қонунчилигига кўра, Мехнат низолари комиссиясида ва туман (шахар) судларида кўриб чиқилиши белгилаб қўйилган. Гарчи, қонунчиликда Мехнат низолари комиссияси мехнат низоларини кўриб чиқувчи ваколатли давлат органларидан бири бўлишига қарамасдан, амалиётда низоларнинг 90 фоизи туман (шахар) фуқаролик судларида кўрилади. Мехнат низоларини суд тартибида хал қилиш кўп холатларда тарафлар учун зиддиятни бартараф этишнинг энг маъқул воситаси хисобланмайди хамда сезиларли миқдордаги суд харажатлари кўринишида зарар етказилади, шахсий ва ишга оид муносабатлар бузилади, шунингдек, низоли холатларнинг исталмаган холда ошкор бўлишига олиб келади. [2] Мустақил мехнат қонунчилигимиз шаклланганига салкам 30 йил бўлган бўлишига қарамасдан, бу сохани саноқли олимларимиз тадқиқ этган. Мехнат низоларини кўриб чиқиш ва хал қилишнинг у ёки бу қирраларини назарий жихатдан М.Рахимов, Ш.Исмоилов, М.Усманова, Г.Саттарова, М.Гасанов сингари олимлар ўз илмий ишларида ўрганиб чиқишган 
бўлса, Й.Турсунов ва Ш.Газиевлар мехнат низолари ва уларни хал этишнинг хуқуқий муаммоларига чуқурроқ ёндашишган.

Ушбу мавзунинг долзарблигини куйидагича ифодалаш мумкин. Мехнат низолари комиссияси мехнат низоларини кўриб чиқувчи ваколатли давлат органларидан бири бўлишига қарамасдан, амалиётда низоларнинг 90 фоизи туман (шахар) фуқаролик судларида кўрилади.

Ушбу мақоланинг асосий мақсади ва вазифаси мехнат низоларига олиб келувчи омиллар тахлили, тарафлари, мехнат низоларини кўриб чиқувчи ва хал қилувчи ваколатли давлат органлар фаолиятига танқидий назар, шунингдек, мехнат низоларини мехнат низолари комиссиясида кўриб чиқишни хуқуқий жихатдан такомиллаштириш мақсадида ривожланган хорижий давлатларнинг ижобий тажрибасини ўрганган холда қонунчиликка аниқ ва мақсадли таклифлар ишлаб чиқишга харакат қилишдир.

Мехнат низоларини кўриб чиқиш ва хал этиш масалаларига Й.Турсунов ва Ш.Газиевлар “Мехнат низолари ва уларни хал этишнинг хуқуқий муаммолари” номли ўқув қўлланмасида атрофлича тўхталиб ўтган. Жумладан, улар томонидан мехнат қонунчилигида илк бор мехнат низолари субъектлар доираси кенгайтирилган холда тахлил қилинганлиги, мехнат низолари комиссияси ва судда низоларнинг кўриб чиқилишига алохида ахамият берилганлиги билан эътиборлидир. Ўқув қўлланмада муаллифлар асосан қиёсий-хуқуқий тахлил методидан кенг фойдаланганлигини гувохи бўлишимиз мумкин.

Мехнат низолари институти мехнат хуқуқининг барча институтларини ўзида қамраб олувчи фундаментал институтларидан бири хисобланади. Бунга сабаб эса, мехнат хуқуқий муносабатларига киришган хар қандай субъект учун мехнат хуқуқи нормаларида белгиланган кафолатлар тўлиқ берилади. Аксарият холларда мехнат муносабатлари субъектлари томонидан ушбу хуқуқ ва мажбуриятларнинг ўз вақтида бажарилмаслиги ёки лозим даражада бажарилмаслиги тарафлардан бирининг манфаатларига зид хисобланиб қолади, натижада мехнатга оид низолар келиб чиқади. Афсуски, Мехнат низолари институти миллий мехнат қонунчилигимизда етарли даражада ўрганилмаган, илмий жихатдан тахлил қилинмаган сохалардан бири бўлиб қолмоқда. Зеро, Халқаро мехнат ташкилоти мехнатга оид низоларни самарали хал этиш мақсадида доимий равишда мехнат низоларини кўриб чиқиш ва хал этишнинг энг самарали йўлларини давлатлар кесимида тахлил қилиб боради, хамда умумлашган тавсия ва қўлланмаларни ишлаб чиқади.

МЕХНАТ НИЗОЛАРИ ТУШУНЧАСИГА амалдаги Ўзбекистон Республикаси мехнат қонунчилигида аниқ таъриф шакллантирилмаган. Шунга қарамасдан, 1995 йилда қабул қилинган Ўзбекистон Республикаси амалдаги мехнат кодексининг 259-моддасида якка мехнат низоларининг тарафлари, мазмуни хамда 281моддасида жамоаларга доир мехнат низоларини (зиддиятларини) кўриб чиқиш тартибининг ёритиб берилиши хам мехнат қонунчилиги ривожига ўз хиссасини қўшганлигини эътироф этишимиз лозим. [3]

Амалдаги мехнат кодексининг 259-моддасига кўра, якка мехнат низолари бу иш берувчи ва ходим ўртасида мехнат тўғрисидаги қонунлар ва бошқа норматив 
хужжатларни, мехнат шартномасида назарда тутилган мехнат шартларини қўлланиш юзасидан келиб чиққан келишмовчиликлардир. Бундай холларда низонинг ходим манфаатини ифода этувчи тарафи бўлиб ходимларнинг вакиллик органи иштирок этиши мумкинлиги назарда тутилган.

Айнан шу кодекснинг 281-моддасида эса, жамоаларга доир мехнат низолари тушунчаси ёритиб берилганлигини гувохи бўлишимиз мумкин. Унга кўра, жамоаларга доир мехнат низолари (зиддиятлари) - бу иш берувчи (иш берувчилар бирлашмаси) ва ходимлар жамоалари (ходимларнинг вакиллик органлари) ўртасида мехнатнинг янги шартларини белгилаш ва мавжуд шартларини ўзгартириш, жамоа шартномалари ва келишувларини тузиш, ўзгартириш ва бажариш юзасидан келиб чиққан келишмовчиликлардир.

Айтиб ўтиш жоизки, норматив хуқуқий хужжатлар лойихалари мухокамаси порталига жойлаштирилган Ўзбекистон Республикаси Мехнат кодекси лойихасининг 579-моддасида илк бор мехнат низолари тушунчасига таъриф бериб ўтилди.

Унга кўра, мехнатга оид низолар -бу иш берувчи ва ўртасида мехнат тўғрисидаги қонунлар ва бошқа норматив хужжатларни, мехнат шартномасида назарда тутилган мехнат шартларини қўллаш юзасидан келиб чиққан келишмовчиликлардир.

Ўзбекистон Республикаси Мехнат кодексининг мехнат низоларини кўриб чиқиш билан боғлиқ нормаси лойихаси имловий, орфографик хамда стилистик хатолар билан қабул қилинмоқда. Шунингдек тугал маъно англашилмайди.

Шу ўринда хорижий давлатлар мехнат қонунчилиги тажрибасига эътибор қаратиш мақсадга мувофиқдир. Мисол учун, Қозоғистон Республикаси Мехнат кодексининг 1-моддаси 16-бандида мехнат низолари тушунчасига ягона таъриф шакллантирилган, унга кўра,

мехнат низолари бу иш берувчи (иш берувчилар) ва ходим (ходимлар) шунингдек, иш берувчи билан илгари мехнат муносабатларида бўлган шахс ўртасида Қозоғистон Республикаси мехнат қонунчилигини қўллаш юзасидан, жамоа шартномаси ва мехнат шартномаси шартларини, шунингдек, иш берувчи томонидан ишлаб чиқарилган локал хужжатларни қўллаш, ўзгартириш юзасидан келиб чиққан келишмовчиликдир. [4]

Америка Қўшма Штатларининг Миллий мехнат муносабатлари тўғрисидаги актнинг (NationalLaborRelationsAct.) 2 қисмида мехнат низолари тушунчасига таъриф бериб ўтилган. Унга кўра, мехнат низолари бу иш берувчи ва ходим ўртасида мехнат шартномасида назарда тутилган вазифалар ёки лавозимларни ижро этиш юзасидан, мехнатни ташкил этиш ёки мехнат шартларини ўзгартириш, бекор қилиш хамда янги мехнат шартларини жорий этиш юзасидан келиб чиққан ўзаро келишмовчиликлардир.[5]

Бизнинг назармизда, Ўзбекистон Республикаси Мехнат кодекси лойихасининг 579-моддасини қуйидагича талқин этиш мақсадга мувофиқдир:[6]

579-модда. Мехнат низолари тушунчаси

Мехнат низолари - бу иш берувчи (иш берувчилар) ва ходим, шунингдек, иш берувчи билан илгари мехнат муносабатларида булган шахс ўртасида мехнат тўғрисидаги қонунлар ва бошқа норматив хуқуқий хужжатларни, жамоа келишуви, 
жамоа шартномаси шунингдек, мехнат шартномаси шартларини қўллаш юзасидан келиб чиққан келишмовчиликлардир.

Шуни қайд этиш лозимки, мехнат низоларига олиб келувчи турли-туман сабаблар мавжуд ва ушбу сабаблар миллий қонуншунос-олимларимиз томонидан айтарли даражада ўрганилмаган ва тахлил қилинмаган. Албатта мехнат низолари мехнат мажбуриятларини бажариш, мехнат хуқуқини қўллаш юзасидан тарафлар ўртасида турли хил субъектив қарашларнинг салбий факторлари хисобланади.

Биринчидан, мехнат қонунчилигини билмаслик ёки лозим даражада билмаслик. Бу холатда иш берувчи хамда ходимларнинг хуқуқий билим ва маданиятининг паст даражага эканлиги. Агар иш берувчининг мехнат хуқуқидан етарли билим ва малакаси бўлмаса, у мехнат қонунчилиги нормаларини корхона фаолиятида нотўғри қўллаши мумкин. Мисол учун, ходим ноқонуний равишда мехнат шартномасини бекор қилади ёки корхонада қонунчиликка зид холда иш вақтини белгилайди.

Иккинчидан, мехнат қонунчилигини турлича талқин этиш хамда мехнатга оид қоидаларни менсимаслик. Бу холат хам корхона ва ташкилот бошқарув органи рахбариятининг мехнатга оид норматив-хуқуқий хужжатларни мазмунан тўғри англаб етмаслиги ёки лозим даражада билмаслиги ва оқибатда мехнат кодекси нормаларини мехнат муносабатларида нотўғри талқин этиш кабилар хам мехнат низоларини юзага келишига олиб келади. Сир эмаски, кўплаб холатларда корхона рахбарияти бошқа хуқуқ сохаларига қараганда айнан, мехнат қонунчилиги нормаларини менсимаслиги, уларда берилган баъзи кўрсатмаларни бажармаслигини гувохи бўламиз.

Учинчидан, афсуски, бошқарув органларида фаолият кўрсатаётган мансабдор шахслар мехнат жамоаси хуқуқларини, ходимлар ўртасида юзага келган мехнат низоларини судгача, муқобил йўлар билан хал қилиш механизмларини чуқур ўзаштирмаганлиги; Корхона ходимлари ва рахбарият ўртасида вужудга келган мехнатга оид келишмовчиликларни корхона хуқуқидан чиқмасдан туриб, яъни мехнат низолари комиссияси орқали хал этиш корхона учун хар томонлама анча арзонга тушиши, хусусан вақт ва маблағнинг бехуда сарфланмаслигини олди олинади.

М.Мамасиддиқовнинг фикрига кўра, мехнат низоларини юзага келишида шахс тафаккури ва хулқ атворидаги камчиликларнинг мавжуд бўлиши, маъмурий буйруқбозлик давридан қолган боқимандачик кайфиятининг сақланиши жамиятда юз бераётган иқтисодий ислохатларга бепарволик, лоқайд муносабатда бўлишлик, хуқуқий маданият савиясининг талаб даражада эмаслиги хам субъектив характердаги мехнат низоларининг юзага келиш сабабларидан биридир [7]

Мехнат низоларининг тааллуқлилигига таъриф бериш борасида хуқуқшунос олимларнинг фикрида жиддий қарама-қаршиликлар мавжуд эмас. Жумладан, Рус олимаси В.Н.Толкунованинг фикрича, мехнат низоларининг тааллуқлилиги деганда мехнат низолари мазмуни ва хусусиятига қараб, дастлаб қайси органда кўриб хал қилиниши демакдир. [8] Ўзбек олими М.Мамасиддиқовнинг фикрича, мехнат низоларининг тааллуқлилиги деганда мехнат низолари мазмуни буйича қайси орган томонидан кўриб хал қилиниши англашилади․․ Қозоқ олимаси Г.Г.Галиакбарованинг тааллуқлилик борасидаги фикри хам юқоридаги олимлар 
фикрига анча яқинлигини гувохи бўлишимиз мумкин. Унинг фикрича, тааллуқлилик- бу мехнат муносабатларининг мазмун-мохиятидан келиб келиб чиқиб, илк бор қайси орган томонидан кўриб чиқилиши лозимлигини билдиради.[9]

Мехнат низоларининг тааллуқлилиги, яъни уларнинг қаерда кўриб чиқилиши лозимлиги Ўзбекистон Республикаси Мехнат кодексининг ва Ўз.Р.Фуқаролик-процессуал кодексининг тегишли моддалари билан тартибга солинган. Мехнат низоларини кўриб чиқувчи органлар, уларни кўриб чиқиш тартиби амалдаги Ўзбекистон Республикаси Мехнат кодексининг тегишли нормаларида ўз аксини топган. Демак, ходим ва иш берувчи ўртасида ўзаро тинч йўл билан хал этилмаган якка мехнат низоларини кўриб чиқиш ва хал этиш ваколати бу сохада иш юритувчи махсус органларга берилган ва улар Ўз.Р.Мехнат кодексининг 260-моддасига мувофиқ қуйидагилардир. [10]

- Корхона ва ташкилотнинг бевосита ўзида ташкил этиладиган ва

фаолият юритадиган мехнат низолари комиссияси;

-фуқаролик ишлари бўйича туманлараро, туман (шахар) судлари;

Бугунги кунда хеч кимга сир эмаски, мехнат низолари комиссияси фаолияти айтарли даражада қониқарли эмас. Бунга эса бир қанча объектив ва субъектив сабабларни кўрсатишимиз мумкин. Бизнинг назаримизда, мехнат низолари комиссиянинг мавжуд бўлиши корхона фаолиятида қуйидаги имкониятларни тақдим этади:

Биринчидан, корхона молиявий чиқимдор бўлмайди. Биламизки, юзага келган мехнат низосини суд тизимида кўриб чиқишда ходим хеч қандай чиқимдор бўлмайди ва мавжуд суд харажатларининг барчаси корхона “гардани” га тушади. Агар юзага келган келишмовчилик бевосита корхона худудида жойлашган мехнат низолари комиссиясида кўриб чиқилса ва хар икки томон манфаатларига зид бўлмаган ечимга келинса, корхона ортиқча иқтисодий чиқим қилмайди. Бундан ташқари, Ўз.Р.Фуқаролик-процессуал кодексининг 114-моддасига мувофиқ, хал қилув қарори қайси тарафнинг фойдасига чиқарилган бўлса, суд шу тарафга иккинчи тарафдан вакилнинг ёрдами учун тўлашга кетган харажатларни оқилона миқдорда ундириб беради. [11]

Иккинчидан, ишлаб чиқариш тўхтаб қолмайди. Корхонада юзага келган низоли вазиятни бартараф этиш хусусан, суд орқали бартараф этиш ишлаб чиқаришдан ажралган холда ортиқча вақтни сарфлашни талаб этади. Албатта, бу вақт оралиғида ходим корхона иқтисодига қанча фойда олиб келиши мумкин эди? Шу боис, айтиш мумкинки, гарчанд юзага келган низо суд тартибида кўриб чиқилсада, барибир корхона манфаатига зид хисобланади.

Учинчидан, низолашаётган субъектлар ўртасида муносабатлар дарз кетмайди. Мехнат муносабатларида юзага келган келишмовчиликлар низо даражасига етиб бормасдан ўз ечимини топади.

Мехнат низоларини суд тартибида хал қилиш кўп холатларда тарафлар учун зиддиятни бартараф этишнинг энг маъқул воситаси хисобланмайди хамда сезиларли миқдордаги суд харажатлари кўринишида зарар етказилади, шахсий ва ишга оид муносабатлар бузилади, шунингдек низоли холатларнинг исталмаган холда ошкор бўлишига олиб келади. [12] 
Мехнат низолари комиссияси корхона ходимлари билан иш берувчи ўртасида юзага келувчи мехнат ихтилофларини кўриб, хал этадиган орган сифатида ходимларнинг ўзлари томонидан ва иш берувчи томонидан ўзаро келишувга кўра ташкил этади ва низолашаётган тарафлар ўртасида ўзаро келиштириш, бир-бирига ён беришга ундаш орқали низони бартараф этиш мақсадини кўзлайди [13]

Гарчи, Ўз.Р.Мехнат кодексининг 264-моддасида мехнат низолари комиссияси мехнат низосини ариза берилган кундан эътиборан ўн кун муддат ичида кўриб чиқиши шартлиги белгилаб қўйилган қоида мавжуд бўлсада, амалиётда ушбу қоидага мехнат низолари комиссияси томонидан амал қилинмаса қандай хукуқий оқибат келиб чиқиши ва бу холатда комиссия аъзоларига нисбатан қандай хуқуқий таъсир чорасини кўриш лозим бўлади мазмунидаги саволларга жавоб Ўз.Р.Мехнат қонунчилигида очиқ қолдирилган.

М.Гридиннинг фикрига кўра, якка мехнат низолари жамоаларга доир мехнат низоларига нисбатан кўпроқ содир бўлади. Шу боис, мехнат низолари коимссиясининг хуқуқий мақомига ўзгартириш киритиш лозим. Мехнат низолари комиссияси вақтинчалик эмас, аксинча доимий фаолият олиб борувчи органга айланиши лозим. Унга мурожаат қилиш хар доим қулай бўлиши керак. [14]

Илгариги Ўз.Р.Мехнат кодексидан фарқли ўлароқ, 1995-йилда қабул қилинган амалдаги мехнат қонунчилигимиз ходимга мехнат низосини хал қилиш учун ўз хохишига кўра, мехнат низолари комиссиясига ёки бевосита судга мурожаат этиш хуқуқларини кафолатлайди. Мехнат кодексининг 269-моддасига кўра, мехнат низоси мехнат низолари комиссиясида кўрилмаган деган важ билан ходимнинг аризасини судда кўриб чиқишни рад йўл қўйилмайди. Демак, мехнат низолари юзасидан ходимнинг эрки чекланмаган яъни, мехнат низоларига мурожаат қилиш ва ундан кейин судга мурожаат қилиш тартиби мавжуд эмас ва қайси органга мурожаат қилишни ходимни ўзи хал қилади.

Мураккаблиги ва оқибатларига кўра юксак ахамиятли бўлган мехнат низолари мехнат низолари комиссиясига тааллуқли бўлмасдан, бундай низолар юқори малакали юрист-судья томонидан кўриб чиқилиши назарда тутилган. [15]

Фуқаролик ишлари туманлараро, туман (шахар) судлари мехнат низоларини кўриб, хал этувчи асосий орган хисобланади ва бугунги кунга қадар мехнат муносабатлари юзасидан келиб чиққан низолар деярли тўлалигича мазкур орган томонидан кўриб хал этилмоқда. Республика фуқаролик ишлари бўйича судлари томонидан 2019 йилда жами 188282 та ишлардан 4233 та мехнат низоларига оид ишлар кўрилган бўлиб, шундан 1964 таси ишга тиклаш, 1279 таси иш хақини ундириш, 196 таси ходим томонидан иш берувчига етказилган зарарни қоплаш ва 700 таси бошқа мехнат низоларига оид ишларни ташкил этганлигини кузатишимиз мумкин. [16]

ХУЛОСА ҚИЛИБ ҚУЙИДАГИ ФИКРЛАРНИ БИЛДИРИШ МУМКИН: МИЛЛИЙ мехнат қонунчилигимизда мехнат низолари тушунчасини ёритиб беришимиз лозим. Мехнат низолари субъектлари доирасини хам кенгайтириб шархлашимиз лозим яъни мехнат низолари субъектлари нафақат иш берувчи ва ходим, балки иш берувчи билан илгари мехнат муносабатларида бўлган собиқ ходим ва иш берувчи билан мехнат муносабатларига киришишини истаган аммо, шартнома шартларига 
келиша олмаган шахс кабилар хам мехнат низоларининг субъекти сифатида мехнат қонунчилигида эътироф этилиши лозим.

Мехнат низолари комиссияси фаолиятини тубдан такомиллаштириш лозим. Бунинг учун амалдаги қонунчилик нормаларига зид келмайдиган ва мехнат низоларини комиссияда кўриб чиқишнинг барча процессуал жихатларини ўзида қамраб олувчи хужжатни ишлаб чиқиш мақсадга муқофиқдир. Мазкур хужжат низом ёки йўриқнома шаклида ваколатли орган орқали тасдиқланиши ва амалиётга кенг жорий этилиши лозим.

Мехнат низоларини суд тартибида хал этишга охирги босқич сифатида қаралмоғи лозим. Бунинг учун, низоларни хал этишнинг муқобил йўлларидан кенг фойдаланишни тадбиқ этиш мақсадга мувофиқдир. Хусусан, айнан мехнатга оид низоларни хал этишда медиациянинг ўрни ва ахамиятини жамоатчилик ичида кенг тарғиб қилишимиз жоиз бўлади.

\section{ФОЙДАЛАНИЛГАН АДАБИЁТЛАР:}

1.Й.Турсунов.Ш.Газиев.Мехнат низолари ва уларни хал этишнинг хуқуқий муаммолари.Т.:2009

2.Мехнат хуқуқий муносабатлардан келиб чиқадиган низолар.Х.Ёдгоров, Г.Зиганшина, Ш.Ахатова.Т.:2017

3. https://lex.uz/docs/142859

4 https://online.zakon.kz/document/?doc_id=38910832

5.

klcohadegdpjf/https://www.ilo.org/dyn/travail/docs/2367/NationalLaborRelationsAct. pdf

6. Мамасиддиқов М.М. Дисс. Мехнатга оид хуқуқий муносабатлардан келиб чиқадиган низоли ишларни судда кўришнинг процессуал хусусиятлари. Т.:2002

7.Толкунова В.Н.Трудовые споры и порядок их разрешения.М.:2017

8.Мамасиддиқов М.М. Дисс. Мехнатга оид хуқуқий муносабатлардан келиб чиқадиган низоли ишларни судда кўришнинг процессуал хусусиятлари. Т.:2002

9.Галиакбарова Г.Г. К вопросу о подведомственности индивидуалых трудовых споров в Республики Казахстан. https://cyberleninka.ru/article/n/k-voprosu-opodvedomstvennosti-individualnyh-trudovyh-sporov-v-respublike-kazahstan

10.https://lex.uz/docs/142859

11. https://lex.uz/docs/3517337

12. Х.Ёдгоров, Г.Зиганшина, Ш.Ахатова. Мехнат хуқуқий муносабатлардан келиб чиқадиган низолар. Baktria press. T.:2017

13.Й.Турсунов. Мехнат кодексига шарх.Т.: “Адолат” -2018

14.Гридин М. Перспективы примерения примирителных процедур при разрешении индивидуального трудового спора. 0protsedurpri\%20razreshenii\%20individualnogo\%20trudovogo\%20spora.pdf

15. Турсунов Й. Мехнат кодексига шарх. Т.: “Адолат”

16. Рахимов.М. Монография. Ходимларнинг мехнат хуқуқларини химоя қилиш. Т.:-2020 